Bond University

Research Repository

\title{
5-HT2A receptor is the predominant receptor mediating contraction of the isolated porcine distal ureter to 5-HT in young and old animals
}

Lim, Iris; Chess-Williams, Russ; Sellers, Donna

Published in:

European Journal of Pharmacology

DOI:

10.1016/j.ejphar.2017.11.001

Licence:

CC BY-NC-ND

Link to output in Bond University research repository.

Recommended citation(APA):

Lim, I., Chess-Williams, R., \& Sellers, D. (2018). 5-HT2A receptor is the predominant receptor mediating contraction of the isolated porcine distal ureter to 5 -HT in young and old animals. European Journal of Pharmacology, 818, 328-334. https://doi.org/10.1016/j.ejphar.2017.11.001

\section{General rights}

Copyright and moral rights for the publications made accessible in the public portal are retained by the authors and/or other copyright owners and it is a condition of accessing publications that users recognise and abide by the legal requirements associated with these rights.

For more information, or if you believe that this document breaches copyright, please contact the Bond University research repository coordinator. 
Pharmacological characterisation of 5-HT receptor subtype/s responsible for mediating contraction of the porcine isolated distal ureter in young and old animals

Iris Lim, Russ Chess-Williams, and Donna Sellers

Centre for Urology Research, Faculty of Health Science \& Medicine, Bond University, QLD 4229, Australia

\section{Corresponding Author:}

Dr Donna Sellers, Centre for Urology Research, Faculty of Health Science \& Medicine, Bond University, QLD 4229, Australia

Email: dsellers@bond.edu.au Tel: +61 (7) 55954778

\section{Declaration of Interest:}

The authors declare that they have no conflicting interests. 


\begin{abstract}
Isolated ureteral strips develop spontaneous phasic contractile activity that is enhanced by 5 -hydroytryptamine $(5-\mathrm{HT})$. The aim of this study was to identify the receptor subtype mediating these responses and to determine whether responses to 5-HT change with age. The frequency of contractions and also the overall contractile activity (measured as the area under the curve, AUC) were recorded in strips of porcine isolated distal ureter from young (3 months) and old (2 years) pigs and responses to 5-HT were examined in the absence and presence of selective 5-HT receptor subtype antagonists. Tissues from the younger animals elicited larger contractile responses to $5-\mathrm{HT}(5885 \pm 334.8 \mathrm{~g} \mathrm{~s})$ than tissues from the older animals $(5787 \pm 334.8 \mathrm{~g} \mathrm{~s}, \mathrm{P}<0.0001)$. The $5-\mathrm{HT}_{2 \mathrm{~A}}$ receptor antagonist ketanserin (10 $100 \mathrm{nM}$ ) elicited rightward shifts of 5-HT concentration-response curves, antagonising AUC and frequency responses with high affinity in both age groups ( $\mathrm{pK}_{\mathrm{D}}$ values 8.48.8). The slopes of the corresponding Schild plots were not significantly different from unity, suggesting a competitive antagonism at a single receptor, except for frequency responses to 5-HT in the older animals. Antagonists for other 5-HT receptor subtypes: methiothepin (non-selective), RS-10221 (5-HT2C), ondansetron (5-HT3), GR-113808 (5-HT4), SB699551 (5-HT5), SB399885 (5-HT6), SB269970 (5HT7)) had no effect on ureteral 5-HT-induced responses. The results suggest that the 5- $\mathrm{HT}_{2 \mathrm{~A}}$ receptor subtype is the predominant receptor in all the tissues, being the sole mediator of responses in young animals, but with another receptor subtype also playing a minor role in the older animals.
\end{abstract}

Keywords: Ureter; 5-HT-receptor; serotonin; ketanserin; ageing; porcine 


\section{Introduction}

5-hydroxytryptamine $(5-\mathrm{HT})$ is found throughout the body and influences smooth muscle activity in various tissues including the intestine, vasculature and urinary bladder (Kim \& Camilleri, 2000; Klarskov \& Horby-Petersen, 1986; MohammadZadeh, Moses, \& Gwaltney-Brant, 2008). The current classification of 5-HT receptors include $5-\mathrm{HT}_{1}(1 \mathrm{~A}, 1 \mathrm{~B}, 1 \mathrm{D}, 1 \mathrm{E}, 1 \mathrm{~F})$ which mediate responses via the inhibition of adenylate cyclase; $5-\mathrm{HT}_{2}(2 \mathrm{~A}, 2 \mathrm{~B}, 2 \mathrm{C})$ which activate phospholipase $\mathrm{C}$; $5-\mathrm{HT}_{3}$ which acts as a ligand-gated ion channel and $5-\mathrm{HT}_{4}$ which is positively coupled to adenylate cyclase. In addition, there are three additional subtypes that are not so well-defined; $5-\mathrm{HT}_{5}$ which inhibit adenylate cyclase and $5-\mathrm{HT}_{6}$ and $5-\mathrm{HT}_{7}$ receptors that activate adenylate cyclase (Roth, 1994).

While many studies on the ureter have been mainly focused on $\alpha$-adrenergic and muscarinic as the major sources of contractile stimulation, $5-\mathrm{HT}$ has been shown to also play a significant role. In isolated strips of human ureter, 5-HT induces concentration-dependent contractions (Barnes, 2001; Gidener, Gumustekin, \& Kirkali, 1999) that are antagonised by the $5-\mathrm{HT}_{2}$ antagonist, ketanserin and the mixed $5-\mathrm{HT}_{1} / 5-\mathrm{HT}_{2}$ receptor antagonist methysergide, but are not altered by $5-\mathrm{HT}_{3}$ and $5-\mathrm{HT}_{4}$ receptors antagonists (Gidener, Kirkali, \& Guven, 1995). Also, the 5-HT2A antagonist ritanserin inhibits contraction of the pig isolated intravesical ureter (Hernandez et al., 2003). In addition, the 5- $\mathrm{HT}_{2 \mathrm{~A}}$ agonist 2,5-dimethoxy-4iodoamphetamine has been reported to increase the frequency of ureteral contractions in pig ureter in vivo in a dose-dependent manner (Hauser et al., 2002).

Ageing has been shown to increase the risk of ureteral calculus development (Hess, 2003) and this could be related to changes in ureteral function, although the effects of age on ureteral responses is unknown. Age-related changes in 5-HT contractile mechanism have been observed in other systems such as the gastrointestinal system (Keating, Nocchi, Yu, Donovan, \& Grundy, 2015) and the inhibitory effect of $5-\mathrm{HT}_{2}$ receptor stimulation in the rat vas deferens has been found to decrease with increasing age (Moritoki, Iwamoto, Kanaya, Ishida, \& Fukuda, 1986). The aim of this study was to identify the receptor subtype mediating ureteral response to $5-\mathrm{HT}$ and to determine whether age has any effect on these responses. 


\section{Methods and Materials}

\subsection{Tissue preparation}

Fresh bladders with ureters attached were obtained from a local abattoir and immediately immersed in ice-cold Krebs-bicarbonate solution $\left(4^{\circ} \mathrm{C}\right)$ composed of $\mathrm{NaCl}(188.4 \mathrm{mM}), \mathrm{NaHCO}_{3}(24.9 \mathrm{mM})$, glucose (11.7mM), $\mathrm{CaCl}_{2}(1.9 \mathrm{mM}), \mathrm{MgSO}_{4}$ (1.2mM) and $\mathrm{KH}_{2} \mathrm{PO}_{4}(1.2 \mathrm{mM})$. Tissues were obtained from 4 month old (young) and 3 year old (old) female pigs. The ureters were detached from the bladders and periureteric fat was removed. The distal ureter was determined as the region $5 \mathrm{~cm}$ from the entrance to the bladder. The tissues were dissected into $4 \mathrm{~mm}$ long tissue strip sections. The tissue strips were mounted longitudinally under $1 \mathrm{~g}$ tension in $8 \mathrm{ml}$ organ baths (EZ-baths, Global Towns, CA) containing Krebs-bicarbonate solution, which was maintained at $37^{\circ} \mathrm{C}$ and continuously gassed with $95 \% \mathrm{O}_{2}$ and $5 \% \mathrm{CO}_{2}$. Isometric tension developed by the tissues was recorded to $P C$ via a Powerlab recording system and Labchart software (ADInstruments, Castle Hill, Australia).

\subsection{Contractile responses to $5-H T$ and $\alpha$-methyl-5-HT}

Complete cumulative concentration-response curves to $5-\mathrm{HT}$ or a-methyl-5-HT (5$\mathrm{HT}_{2}$ agonist) were obtained in isolated ureteral tissues from both age groups in the absence and presence of the selective 5- $\mathrm{HT}_{2 \mathrm{~A}}$ receptor antagonist ketanserin (10 $100 \mathrm{nM}$ ). Additionally, concentration-response curves to $5-\mathrm{HT}$ were also obtained in the absence and presence of the non-selective 5-HT antagonist methiothepin (10nM), 5- $\mathrm{HT}_{2 \mathrm{C}}$ antagonist RS-10221 (30nM), 5- $\mathrm{HT}_{3}$ antagonist ondansetron (30nM), 5- $\mathrm{HT}_{4}$ antagonist GR-113808 (100nM), 5- $\mathrm{HT}_{5}$ antagonist SB699551 (10nM), 5- $\mathrm{HT}_{6}$ antagonist SB399885 (100nM) and 5-HT7 antagonist SB269970 (10nM). Concentrations producing a selective antagonism for a particular receptor were chosen based on affinity values obtained from the literature.

Only one concentration-response curve was obtained on each tissue. Preparations from the same ureter were compared in each individual experiment, with at least two preparations acting as controls without the addition of any antagonist.

\subsection{Data Analysis}


Graphpad PRISM software was used for statistical analyses. Mean ( \pm S.E.M.) increases in area under the curve (AUC) relative to weight in grams seconds (g s) and frequency responses in Hertz $(\mathrm{Hz})$ were calculated. Mean ( \pm S.E.M.) maximum responses and $-\operatorname{logEC50}$ (pEC50) values were also recorded for each concentration-response curve. Paired Student's t-tests were performed on studies with two groups, while two-way ANOVA was used for studies involving more than two groups.

Dissociation constant estimates (apparent $\mathrm{pK}_{\mathrm{B}}$ ) for antagonists were determined from the equation: $\mathrm{pK}_{\mathrm{B}}=\log (\mathrm{CR}-1)-\log [\mathrm{B}]$, where $\mathrm{CR}$ is the concentration ratio (ratio of the $\mathrm{EC}_{50}$ values) in the absence and presence of the antagonist obtained with a concentration $[\mathrm{B}]$ of antagonist. Schild plots were also constructed (Arunlakshana \& Schild, 1959) where data from several antagonist concentrations was available.

\subsection{Drugs}

The following drugs were used: $5-\mathrm{HT}$ hydrochloride (Abcam), a-methyl-5-HT maleate (Tocris), methiothepin mesylate salt (Sigma-Aldrich), ketanserin (+)-tartrate salt (Sigma-Aldrich), RS-102221 (Tocris), ondansetron hydrochloride dehydrate (SigmaAldrich), GR-113808 (Tocris), SB 699551 (Sigma-Aldrich), SB-399885 hydrochloride (Sigma-Aldrich) and SB-269970 hydrochloride (Sigma-Aldrich). All drugs were dissolved in distilled water before added to the bathing solution. 


\section{Results}

\subsection{The effect of age on 5-HT-induced contractile responses}

When subjected to increasing concentrations of $5-\mathrm{HT}$ or the $5-\mathrm{HT}_{2}$ selective agonist a-methyl-5HT, all ureteral strips from both age groups developed bursts of phasic contractions and overall contractile activity increased when measured as area under the curve and expressed relative to tissue weight (AUC, $g$ s). Increasing concentrations of $5-\mathrm{HT}$ also resulted in an increase in frequency of phasic activity which was measured in $\mathrm{Hz}$ (Fig 1). The potency ( $\mathrm{pEC}_{50}$ ) of $5-\mathrm{HT}$ was similar for tissues from both age groups (Table 2). However, maximal contractile responses measured as AUC were smaller in tissues from the older animals compared to the younger animals $(p<0.001$, unpaired Student's $t$-test, Fig. $1 a)$, while maximum frequency responses were similar in the two age groups (Fig. 1b).

\subsection{5-HT- and $\alpha$-methyl-5-HT-induced contractile responses}

Similarly, when subjected to increasing concentrations of the 5-HT2A selective agonist $\alpha$-methyl-5-HT, the tissues from both age groups developed bursts of phasic contractions that were measured as AUC and frequency.

\subsection{The effect of ketanserin on 5-HT and a-methyl-5-HT induced contractile responses}

For both frequency responses and overall contractile (AUC) responses, ketanserin at relatively low concentrations (10 - 100nM) caused significant rightward shifts of 5-HT concentration-response curves in both age groups (Figs 2 and 3). In addition, maximal contractile responses to 5-HT for both $\mathrm{AUC}$ and frequency responses appeared to be depressed in the presence of ketanserin ( $p<0.05$, two-way ANOVA, Figs 2 and 3). However, maximum responses could not always be obtained and a comparison of the slopes of the concentration-response curves in each group was performed. There were no statistically significant change in the slopes of any of the curves, suggesting a competitive antagonism. Using $\mathrm{EC}_{40}$ values for responses (expressed as AUC and frequency), Schild analysis was performed on data for tissues from both age groups and $\mathrm{pA}_{2}$ values (intercept on $\mathrm{X}$-axis) determined (Table 1). Ketanserin had a relatively high affinity for the receptors in this tissue and the slopes of the Schild plots were not significantly different from unity, again suggesting 
a competitive antagonism. The exception was the frequency of phasic contractions in tissues from older animals, where the slope was significantly steeper than unity (Fig 3b).

Ketanserin $(10-100 \mathrm{nM})$ also caused rightward shifts of concentration-response curves to a-methyl-5-HT in tissues from both age groups. Again there was no significant change in the slope of concentration-response curves to this agonist. Schild plots again had slopes similar to unity and yielded the $\mathrm{pA}_{2}$ values ( $\mathrm{X}$-axis intercepts) presented in Table 1.

3.4 The effects of 5-HT receptor antagonists on 5-HT-induced contractile responses None of the receptor subtype selective 5-HT antagonists RS-102221 (30nM, 5-HT $2 \mathrm{C}$ selective), ondansetron (30nM, 5- $\mathrm{HT}_{3}$ selective), GR-113808 (100nM, 5- $\mathrm{HT}_{4}$ selective), SB 699551 (10nM, 5- $\mathrm{HT}_{5}$ selective), SB 399885 (100nM, 5-HT6 selective) or SB 269970 (10nM, 5-HT7 selective) affected maximal contractile responses or $\mathrm{pEC} 50$ values for $5-\mathrm{HT}$. Mean $\mathrm{pEC50}$ values and maximum responses for frequency and $A U C$ responses were similar in the absence and presence of each antagonist and this was true for tissues from both young and old animals (Table 2).

The non-selective 5-HT receptor antagonist methiothepin (10nM) significantly reduced responses to $5-\mathrm{HT}$ in ureters from younger animals with both the frequency responses and the AUC responses being significantly reduced in the presence of this antagonist $(p<0.005$, paired Student's $t$-test). However this inhibitory effect of methiothepin was not observed in tissues from the older animals (Fig 4). Additionally in the tissues from young, but not old animals, methiothepin shifted the 5-HT curves to the right and significantly reduced $\mathrm{pEC}_{50}$ values for frequency responses to $5 \mathrm{HT}$ (Table 2, Fig 4). 


\section{Discussion}

Previously, it has been demonstrated that 5-HT stimulates contraction of smooth muscle in isolated ureteral strips in a number of species (Gidener et al., 1999; Gidener et al., 1995; Hernandez et al., 2003). In the current study, similarly, 5-HT induced concentration-dependent increases in contractile activity, increasing both the frequency and magnitude of phasic contractions in distal ureters from older and younger pigs. This is in agreement with most other findings in tissues from pig and human (Gidener et al., 1999; Gidener et al., 1995; Hernandez et al., 2003), but contrasts with a study in rabbit isolated tissues that failed to find any ureteral response to $5-\mathrm{HT}$, suggesting that these responses are species dependent and the pig represents a good model for human (Yalcin et al., 2013).

In our present porcine study, 5-HT produced concentration-dependent increases in overall phasic contractile activity (AUC) and frequency. A similar finding has been reported by Hernandez et al, (2003) for the porcine intravesical ureter. However, in that study, 5-HT preferentially increased contractile tone, but the frequency of these phasic contractions was not related to 5-HT concentration (Hernandez et al., 2003). These authors also found that phasic contractions were abolished during 5-HTevoked increases in ureteral tone (Hernandez et al., 2003). In our studies no increases in baseline tone were observed upon addition of either 5-HT or a-methyl-5HT at any concentration. This observed difference can be explained by the difference in ureteral region being studied. The intravesical ureter region utilised in their experiments acts as a sphincter controlling movement of urine into the bladder (Blok, Van Venrooij, Mokhless, \& Coolsaet, 1985; Hernandez, Barahona, Bustamante, Garcia-Sacristan, \& Orensanz, 1999; Prieto, Hernandez, Rivera, Garcia-Sacristan, \& Simonsen, 1997), whilst the distal ureter was examined in the present study. It therefore appears that $5-\mathrm{HT}$ plays different, region specific roles in the urinary tract.

pEC50 values for $5-\mathrm{HT}$ were unaffected by age. Because $5-\mathrm{HT}$ is a full agonist for its receptors, it is unlikely that the decrease in maximal 5-HT-induced contraction with age is due to changes in receptor expression but instead due to altered efficacy of receptor stimulation. It is suggested that the differences in 5-HT-stimulated 
contractile responses with age presented here could be due to alterations in the involvement of other receptor subtypes to contractility with age.

In young animals, the $5-\mathrm{HT}_{2 \mathrm{~A}}$ receptor antagonist ketanserin, at relatively low concentrations, shifted $5-\mathrm{HT}$ concentration-response curves rightward, suggesting a role for $5-\mathrm{HT}_{2 \mathrm{~A}}$ receptors in mediating $5-\mathrm{HT}$-induced contractions of the ureter. The slopes of ketanserin Schild plots for the antagonism of frequency and AUC responses were not significantly different from unity, suggesting that $5-\mathrm{HT}_{2 \mathrm{~A}}$ is the sole receptor subtype responsible for these responses. Furthermore, in these tissues from younger animals, the affinity estimates for ketanserin were comparable to value (8.7) reported at the $5-\mathrm{HT}_{2 \mathrm{~A}}$ receptor in the literature (Bonhaus et al., 1995). Also in tissues from younger animals, there was a slight rightward shift of the 5-HT concentration-response curve in the presence of methiothepin, a generally nonselective $5-\mathrm{HT}$ antagonist, but with an affinity highest at the 5- $\mathrm{HT}_{2 \mathrm{~A}}$ receptor subtype (Hoyer et al., 1994). This again suggests the involvement of the 5-HT2A receptor subtype.

This conclusion is further supported by the lack of effect of all the other 5-HT receptor subtype selective antagonists. Based on the affinity values published in the literature, for each antagonist a concentrations was chosen that would produce a significant blockade of the specific receptor subtype, without an action at the other receptor subtypes. However none of the antagonists had any effect on concentration-response curves to 5-HT supporting the results obtained with ketanserin and again suggesting that $5 \mathrm{HT}_{2 \mathrm{~A}}$ is the only receptor subtype involved in mediating the responses to $5-\mathrm{HT}$.

In ureteral tissues from older animal, ketanserin again had a relatively high affinity, although a little lower than that obtained in the younger animals. For frequency responses to $5-\mathrm{HT}$, the Schild plot for ketanserin had a slope that was significantly greater than unity indicating additional antagonistic actions of ketanserin in ureters from the older animals. For this reason the affinity estimate of 7.7 obtained from the intercept of the Schild plot for frequency responses is most likely not reflective of the true affinity value for ketanserin. Additionally, the affinity estimate for AUC responses to $5-\mathrm{HT}$ in tissues from the older animals was lower (8.0) than values in the literature 
and the value obtained in tissues from younger animals. Also, the rightward shift of the 5-HT response curves in the tissues from the younger animals when incubated with methiothepin was not observed in the older animals.

Affinity estimates for ketanserin at $5-\mathrm{HT}_{2 \mathrm{~A}}$ receptors with a-methyl-5-HT stimulation in older animals were also comparable to values (8.7) found in the literature (Bonhaus et al., 1995), indicating that the additional effect of methiothepin is unlikely to be via $5-\mathrm{HT}_{2 B}$ or $5-\mathrm{HT}_{2 \mathrm{C}}$ receptors. This is further supported by the lack of inhibition of 5-HT contractile response by the $5-\mathrm{HT}_{2 \mathrm{C}}$ selective antagonist, RS-10221. Therefore, it appears that in the younger animals, the 5-HT-induced contractile response is due to stimulation of the $5-\mathrm{HT}_{2 \mathrm{~A}}$ receptor subtype, whilst in the older animals, the $5-\mathrm{HT}_{2 \mathrm{~A}}$ receptor is responsible for the contractile effect of $5-\mathrm{HT}$ and the stimulation of $5-\mathrm{HT}$ on another receptor could cause a relaxatory effect. This is also a possible explanation for the depressed $5-\mathrm{HT}$ contractile responses in tissues from the older animals.

Despite functional studies demonstrating the role of $5-\mathrm{HT}$ in ureteral contractility, the source of endogenous $5-\mathrm{HT}$ in the ureter is unclear. Since 5-HT-containing enterochromaffin cells which are present in the gastrointestinal tract could not be found in the ureter (Nocito et al., 2007; Ripoche, 2011; Theoharides, Bondy, Tsakalos, \& Askenase, 1982), it appears that platelets and mast cells might be the source of $5-\mathrm{HT}$ in this tissue. Particularly where intra-ureteral pressure may increase due to the presence of calculi, it is possible that increased vascular permeability secondary to inflammation could result in platelet release of 5-HT in the tissues. Alternatively, mast cells playing a major role in the inflammatory process have been observed in all layers of the porcine ureteral wall under normal conditions (Jerde, Saban, Bjorling, Steinberg, \& Nakada, 2000; Vodenicharov, Leiser, Gulubova, \& Vlaykova, 2005). Mast cells present in the ureter are most likely involved in maintaining local homeostasis and also play an important role in the regulation of ureteral motility via the release of mediators including histamine and 5-HT in inflammatory circumstances. While our preliminary data failed to find any ureteral response to histamine, it is possible that mast cell regulatory mechanisms occurs via $5-\mathrm{HT}$. Furthermore, an upregulation of $5-\mathrm{HT}_{2 \mathrm{~A}}$ receptors may occur during obstruction and in the rabbit ureter it has been shown that 5 -HT-stimulated 
contractile responses are enhanced in the presence of ureteral obstruction (Yalcin et al., 2013).

\section{Conclusion}

The present data indicate that 5-HT enhances the overall phasic contractile activity of the porcine ureter by increasing both the frequency and magnitude of contractions. With increasing age, overall contractile activity is depressed, but without changes in the frequency responses to $5-\mathrm{HT}$. The predominant receptor mediating both frequency and contractile responses to $5-\mathrm{HT}$ is the $5-\mathrm{HT} 2 \mathrm{~A}$ receptor subtype and this does not appear to change with increasing age. While in vivo experiments are still required, the $5-\mathrm{HT}$ receptor-mediated pathway seems to be upregulated following ureteral obstruction, and therefore, this system could prove to be an effective target for treatment of ureteral calculi. The changes with age that was observed in the present study could also prove to be useful when administering treatment to different age groups.

\section{Acknowledgements:}

Iris Lim received a Bond University Higher Degree Research Scholarship. 


\section{References}

Arunlakshana, O., \& Schild, H. O. (1959). Some quantitative uses of drug antagonists. Br J Pharmacol, 14(1), 48-58.

Barnes, P. J. (2001). Histamine and serotonin. Pulm Pharmacol Ther, 14(5), 329339. doi: $10.1006 /$ pupt.2000.0318

Blok, C., Van Venrooij, G. E., Mokhless, I., \& Coolsaet, B. L. (1985). Dynamics of the ureterovesical junction: its fluid transport mechanism in the pig. J Urol, 134(1), 175-178.

Bonhaus, D. W., Bach, C., DeSouza, A., Salazar, F. H., Matsuoka, B. D., Zuppan, P., . . Eglen, R. M. (1995). The pharmacology and distribution of human 5hydroxytryptamine2B (5-HT2B) receptor gene products: comparison with 5HT2A and 5-HT2C receptors. Br J Pharmacol, 115(4), 622-628.

Gidener, S., Gumustekin, M., \& Kirkali, Z. (1999). Pharmacological analysis of 5hydroxytryptamine effects on human isolated ureter. Pharmacol Res, 39(6), 487-491. doi: 10.1006/phrs.1999.0469

Gidener, S., Kirkali, Z., \& Guven, H. (1995). Influence of serotonin on the human ureter: an in vitro pharmacological study. Urol Int, 55(4), 202-204.

Hauser, D. S., Mevissen, M., Weiss, R., Portier, C. J., Scholtysik, G., Studer, U. E., \& Danuser, H. (2002). Effects of ketanserin and DOI on spontaneous and 5-HTevoked peristalsis of the pig ureter in vivo. Br J Pharmacol, 135(4), 10261032. doi: $10.1038 /$ sj.bjp.0704536

Hernandez, M., Barahona, M. V., Bustamante, S., Garcia-Sacristan, A., \& Orensanz, L. M. (1999). A2B adenosine receptors mediate relaxation of the pig intravesical ureter: adenosine modulation of non adrenergic non cholinergic excitatory neurotransmission. Br J Pharmacol, 126(4), 969-978. doi: 10.1038/sj.bjp.0702386

Hernandez, M., Barahona, M. V., Simonsen, U., Recio, P., Rivera, L., Martinez, A. C., ... Prieto, D. (2003). Characterization of the 5-hydroxytryptamine receptors mediating contraction in the pig isolated intravesical ureter. $\mathrm{Br} \mathrm{J}$ Pharmacol, 138(1), 137-144. doi: 10.1038/sj.bjp.0705019

Hess, B. (2003). [Pathophysiology, diagnosis and conservative therapy in calcium kidney calculi]. Ther Umsch, 60(2), 79-87. doi: 10.1024/0040-5930.60.2.79

Hoyer, D., Clarke, D. E., Fozard, J. R., Hartig, P. R., Martin, G. R., Mylecharane, E. J., . . . Humphrey, P. P. (1994). International Union of Pharmacology classification of receptors for 5-hydroxytryptamine (Serotonin). Pharmacol Rev, 46(2), 157-203.

Jerde, T. J., Saban, R., Bjorling, D. E., Steinberg, H., \& Nakada, S. Y. (2000). Distribution of neuropeptides, histamine content, and inflammatory cells in the ureter. Urology, 56(1), 173-178.

Keating, C., Nocchi, L., Yu, Y., Donovan, J., \& Grundy, D. (2015). Ageing and gastrointestinal sensory function: Altered colonic mechanosensory and chemosensory function in the aged mouse. J Physiol. doi: 10.1113/JP271403

Kim, D. Y., \& Camilleri, M. (2000). Serotonin: a mediator of the brain-gut connection. Am J Gastroenterol, 95(10), 2698-2709. doi: 10.1111/j.15720241.2000.03177.x

Klarskov, P., \& Horby-Petersen, J. (1986). Influence of serotonin on lower urinary tract smooth muscle in vitro. Br J Urol, 58(5), 507-513. 
Mohammad-Zadeh, L. F., Moses, L., \& Gwaltney-Brant, S. M. (2008). Serotonin: a review. J Vet Pharmacol Ther, 31(3), 187-199. doi: 10.1111/j.13652885.2008.00944.x

Moritoki, H., Iwamoto, T., Kanaya, J., Ishida, Y., \& Fukuda, H. (1986). Age-related change in serotonin-mediated prejunctional inhibition of rat vas deferens. Eur J Pharmacol, 132(1), 39-46.

Nocito, A., Georgiev, P., Dahm, F., Jochum, W., Bader, M., Graf, R., \& Clavien, P. A. (2007). Platelets and platelet-derived serotonin promote tissue repair after normothermic hepatic ischemia in mice. Hepatology, 45(2), 369-376. doi: 10.1002/hep.21516

Prieto, D., Hernandez, M., Rivera, L., Garcia-Sacristan, A., \& Simonsen, U. (1997). Distribution and functional effects of neuropeptide $Y$ on equine ureteral smooth muscle and resistance arteries. Regul Pept, 69(3), 155-165.

Ripoche, J. (2011). Blood platelets and inflammation: their relationship with liver and digestive diseases. Clin Res Hepatol Gastroenterol, 35(5), 353-357. doi: 10.1016/j.clinre.2011.02.012

Roth, B. L. (1994). Multiple serotonin receptors: clinical and experimental aspects. Ann Clin Psychiatry, 6(2), 67-78.

Theoharides, T. C., Bondy, P. K., Tsakalos, N. D., \& Askenase, P. W. (1982). Differential release of serotonin and histamine from mast cells. Nature, 297(5863), 229-231.

Vodenicharov, A., Leiser, R., Gulubova, M., \& Vlaykova, T. (2005). Morphological and immunocytochemical investigations on mast cells in porcine ureter. Anat Histol Embryol, 34(6), 343-349. doi: 10.1111/j.1439-0264.2005.00618.x

Yalcin, S., Ertunc, M., Ardicli, B., Kabakus, I. M., Tas, T. S., Sara, Y., . . Karnak, I. (2013). Ureterovesical junction obstruction causes increment in smooth muscle contractility, and cholinergic and adrenergic activity in distal ureter of rabbits. J Pediatr Surg, 48(9), 1954-1961. doi:

10.1016/j.jpedsurg.2013.01.030 
Table 1

Affinity estimates ( $\mathrm{pA}_{2}$ values) for ketanserin on distal ureter using 5HT or $\alpha-m e t h y l-5-H T$ as the agonists

\begin{tabular}{|c|c|c|c|c|}
\hline Agonist & $\begin{array}{l}\text { Animal } \\
\text { age }\end{array}$ & Response & $\begin{array}{l}\mathrm{pA}_{2} \\
\text { estimate }\end{array}$ & Schild Slope \\
\hline \multirow{4}{*}{$5-\mathrm{HT}$} & \multirow{2}{*}{ Young } & AUC & 8.67 & $0.79 \pm 0.07$ \\
\hline & & Frequency & 8.42 & $0.81 \pm 0.07$ \\
\hline & \multirow{2}{*}{ Old } & AUC & 8.09 & $1.25 \pm 0.18$ \\
\hline & & Frequency & 7.69 & $1.40 \pm 0.02$ * \\
\hline \multirow{4}{*}{ a-methyl-5-HT } & \multirow{2}{*}{ Young } & AUC & 8.41 & $1.05 \pm 0.12$ \\
\hline & & Frequency & 8.80 & $1.12 \pm 0.29$ \\
\hline & \multirow{2}{*}{ Old } & AUC & 8.41 & $1.22 \pm 0.10$ \\
\hline & & Frequency & 8.53 & $1.20 \pm 0.34$ \\
\hline \multicolumn{5}{|c|}{$\begin{array}{l}\text { Apparent } \mathrm{pK}_{\mathrm{D}} \text { values for ketanserin }(10-100 \mathrm{nM}) . \mathrm{pK} \mathrm{K}_{\mathrm{D}} \text { values are the } \\
\text { intercept on the } \mathrm{x} \text {-axis of the Schild plot. }{ }^{*} \text { Schild Slope significantly } \\
\text { different from unity }\end{array}$} \\
\hline
\end{tabular}


Table 2

pEC50 values for $5-\mathrm{HT}$ in the presence and absence of antagonists

\begin{tabular}{|c|c|c|c|c|}
\hline \multirow{2}{*}{ Antagonists } & \multirow{2}{*}{$\begin{array}{l}\text { Animal } \\
\text { age }\end{array}$} & \multirow{2}{*}{ Response } & \multicolumn{2}{|c|}{ pEC50 } \\
\hline & & & Absent & Present \\
\hline \multirow{4}{*}{$\begin{array}{l}\text { 10nM } \\
\text { methiothepin } \\
\text { (non-selective) }\end{array}$} & \multirow{2}{*}{ Young } & $\mathrm{AUC}$ & $5.26 \pm 0.05$ & $4.72 \pm 0.05^{\star}$ \\
\hline & & Frequency & $5.51 \pm 0.09$ & $5.19 \pm 0.10$ \\
\hline & \multirow{2}{*}{ Old } & $\mathrm{AUC}$ & $5.34 \pm 0.06$ & $5.60 \pm 0.24$ \\
\hline & & Frequency & $5.80 \pm 0.15$ & $5.83 \pm 0.12$ \\
\hline \multirow{4}{*}{$\begin{array}{l}\text { 30nM RS- } \\
10221\left(5-\mathrm{HT}_{2 \mathrm{C}}\right)\end{array}$} & \multirow{2}{*}{ Young } & $\mathrm{AUC}$ & $5.27 \pm 0.08$ & $5.29 \pm 0.07$ \\
\hline & & Frequency & $5.58 \pm 0.16$ & $5.53 \pm 0.14$ \\
\hline & \multirow{2}{*}{ Old } & $\mathrm{AUC}$ & $5.01 \pm 0.17$ & $4.98 \pm 0.31$ \\
\hline & & Frequency & $5.29 \pm 0.22$ & $5.42 \pm 0.13$ \\
\hline \multirow{4}{*}{$\begin{array}{l}\text { 30nM } \\
\text { ondansetron } \\
\left(5-\mathrm{HT}_{3}\right)\end{array}$} & \multirow{2}{*}{ Young } & $\mathrm{AUC}$ & $5.22 \pm 0.08$ & $5.15 \pm 0.12$ \\
\hline & & Frequency & $5.39 \pm 0.10$ & $5.36 \pm 0.14$ \\
\hline & \multirow{2}{*}{ Old } & $\mathrm{AUC}$ & $5.27 \pm 0.12$ & $5.12 \pm 0.12$ \\
\hline & & Frequency & $5.45 \pm 0.21$ & $5.14 \pm 0.13$ \\
\hline \multirow{4}{*}{$\begin{array}{l}\text { 100nM } \\
\text { GR-113808 } \\
\left(5-\mathrm{HT}_{4}\right)\end{array}$} & \multirow{2}{*}{ Young } & $\mathrm{AUC}$ & $5.00 \pm 0.12$ & $5.08 \pm 0.09$ \\
\hline & & Frequency & $5.19 \pm 0.17$ & $5.19 \pm 0.16$ \\
\hline & \multirow{2}{*}{ Old } & $A \cup C$ & $5.37 \pm 0.10$ & $5.23 \pm 0.12$ \\
\hline & & Frequency & $5.73 \pm 0.36$ & $5.63 \pm 0.44$ \\
\hline \multirow{4}{*}{$\begin{array}{l}\text { 10nM } \\
\text { SB 699551 } \\
\left(5-\mathrm{HT}_{5}\right)\end{array}$} & \multirow{2}{*}{ Young } & $\mathrm{AUC}$ & $4.84 \pm 0.15$ & $4.77 \pm 0.21$ \\
\hline & & Frequency & $4.90 \pm 0.18$ & $5.01 \pm 0.22$ \\
\hline & \multirow{2}{*}{ Old } & $\mathrm{AUC}$ & $4.84 \pm 0.19$ & $5.22 \pm 0.21$ \\
\hline & & Frequency & $5.28 \pm 0.18$ & $5.65 \pm 0.28$ \\
\hline \multirow{4}{*}{$\begin{array}{l}\text { 100nM } \\
\text { SB 399855 } \\
\left(5-\mathrm{HT}_{6}\right)\end{array}$} & \multirow{2}{*}{ Young } & $\mathrm{AUC}$ & $4.92 \pm 0.15$ & $4.98 \pm 0.12$ \\
\hline & & Frequency & $5.10 \pm 0.22$ & $5.09 \pm 0.26$ \\
\hline & \multirow{2}{*}{ Old } & $\mathrm{AUC}$ & $5.01 \pm 0.25$ & $4.93 \pm 0.10$ \\
\hline & & Frequency & $5.20 \pm 0.16$ & $5.17 \pm 0.08$ \\
\hline \multirow{4}{*}{$\begin{array}{l}10 \mathrm{nM} \\
\text { SB 269970 } \\
\left(5-\mathrm{HT}_{7}\right)\end{array}$} & \multirow{2}{*}{ Young } & $\mathrm{AUC}$ & $5.11 \pm 0.11$ & $5.21 \pm 0.05$ \\
\hline & & Frequency & $5.31 \pm 0.08$ & $5.51 \pm 0.12$ \\
\hline & \multirow{2}{*}{ Old } & $\mathrm{AUC}$ & $4.98 \pm 0.12$ & $5.12 \pm 0.20$ \\
\hline & & Frequency & $5.00 \pm 0.21$ & $5.09 \pm 0.17$ \\
\hline
\end{tabular}




\section{Figure 1}

Concentration-response curves to $5-\mathrm{HT}$ in distal ureteral tissues from old and young pigs. Responses are expressed as AUC by weight in $\mathrm{g}^{-1} \mathrm{~s}$ (a) and frequency in $\mathrm{Hz}$ (b). Results are presented as mean \pm SEM of 8 preparations for each group. $\left({ }^{*} p<0.05,{ }^{* * *} p<0.005\right.$ vs corresponding value for young)

\section{Figure 2}

Concentration-response curves to $5-\mathrm{HT}$ in isolated distal ureter from young pigs, in the presence and absence of ketanserin (10-100nM). Responses are expressed as $\%$ of maximal response for AUC (A) and frequency (B). Corresponding Schild plots are also shown. Results are presented as mean \pm SEM of 8 preparations for each group.

\section{Figure 3}

Concentration-response curves to $5-\mathrm{HT}$ in isolated distal ureter from old pigs, in the presence and absence of ketanserin (10-100nM). Responses are expressed as \% of maximal response for $A \cup C(A)$ and frequency $(B)$. Corresponding Schild plots are also shown. Results are presented as mean \pm SEM of 8 preparations for each group.

\section{Figure 4}

Concentration-response curves to $5-\mathrm{HT}$ in the presence and absence of the 5-HT antagonist methiothepin (10nM). Results for isolated distal ureter from young $(A)$ and old (B) pigs are shown. Responses are expressed as a percentage of maximal responses. Results are presented as mean \pm SEM of 8 preparations for each group $\left({ }^{*} \mathrm{p}<0.05,{ }^{* *} \mathrm{p}<0.005,{ }^{* \star *} \mathrm{p}<0.001\right.$ vs control). 